\title{
Speaking the Self, Narratives on Srebrenica
}

\section{Odile Heynders}

Tilburg University, The Netherlands

\section{ABSTRACT IN ENGLISH}

This article explores life narratives documenting the fall of the Srebrenica enclave in July 1995. I am interested in the personal experiences, in the different perspectives in regard to historical facts, in the narrative power of imagination, and in the potential of an authentic voice. The fundamental question addressed, is how a story constructs a self in the context of a specific (tragic) European locus, and offers at the same time an understanding of the polyphony in a geopolitical space. The main theoretical frame employed in this paper is narrative and life writing theory, pointing at the articulation of a self as a living, telling and imagining human being. From discourse analysis I use the notion of polyphony resulting in a reconsideration of social structures. The objects I will focus on are a testimony, a chronicle and a project of photographs linked to autobiographical statement.

\section{ABSTRACT IN DUTCH}

Dit artikel gaat in op levensverhalen waarin de val van de Srebrenica enclave in juli 1995 wordt gedocumenteerd. Ik besteed aandacht aan de persoonlijke ervaringen, de verschillende perspectieven met betrekking tot historische gegevens, en ga in op de narratieve kracht van de verbeelding en het potentieel van een authentieke stem. De fundamentele vraag die hierbij aan de orde komt, is hoe een verhaal een zelf construeert binnen de context van een specifieke (tragische) Europese plaats, terwijl dit artikel tegelijkertijd een begrip biedt van de meerstemmigheid binnen een geopolitieke ruimte. Het belangrijkste theoretische raamwerk dat in dit artikel wordt gebruikt, is de theorie met betrekking tot narratief en life writing, waarin de articulatie van het zelf als een levende, vertellende en verbeeldende mens centraal staat. Daarbij maak ik 
gebruik van het begrip polyfonie zoals dat gehanteerd wordt in de discours analyse, wat leidt tot een herbezinning van sociale structuren. De objecten waarop ik mij hierbij richt zijn een getuigenverslag, een kroniek en een fotoproject dat deel uitmaakt van een autobiografisch verslag.

Keywords: Srebrenica, voice, polyphony, authenticity, imagination

\section{INTRODUCTION}

In July 1995, a safe area in East-Bosnia - a space of $15 \mathrm{~km}$ around the city of Srebrenica supposed to offer protection to Muslim people and guarded by Dutchbat III, a UN mission of 400 Blue Berets - was invaded and destroyed by the Bosnian Serb Army (BSA). In the course of four days, more than 7,400 men and boys were executed while older men, women and children were forced to flee. The massacre counts as the single largest war crime in Europe since the Second World War (Honig and Both 1996, p. xix). The Dutch battalion was not able to offer resistance to the BSA and was afterwards considered to be co-responsible for the tragedy (Judt 2007, p. 677). When dealing with contemporary history, we have to be aware of differences between facts and memory, official information and individual experience, or reflection and imagination. Distinctions can be made between the general narrative and personal stories. But the question is, what exactly makes a story personal, and in consequence, how we are able to understand the collective narrative without erasing the particular voices?

In the eighteen years that have elapsed since the fall of Srebrenica, many narratives have been published, personal stories have been told, and official reports have been made available. There are books on the subject, academic studies, documentaries, films and so on. ${ }^{1}$ As individual stories accumulate and circulate beyond the local context, the collective narrative gains cultural importance and resonance. Kay Schaffer and Sidonie Smith, in Human Rights and Narrated Lives, observe: "Stories unsettle private beliefs and public discourses about the national past, generating public debate, sympathy and outrage" (p. 4). Personal stories disturb existing consensus in the public sphere, challenging official history at odds with accepted versions of what happened, echoing the various voices, experiences and memories of people who witnessed the events.

The official history of Srebrenica tells about the complex geopolitical situation and the failures of the European Union and the United Nations. Tony Judt's Postwar, A History of Europe since 1945 (2005) offers detailed explanations in regard to this official story: "Between 1991 and 
1999 hundreds of thousands of Bosnians, Croats, Serbs and Albanians were killed, raped or tortured by their fellow citizens; millions more were forced out of their homes and into exile" (p. 665). ${ }^{2}$ Before the war the country was an interwoven tapestry of overlapping minorities in which residents of ethnically mixed regions often had little sense of their neighbors' nationality or religion, and inter-marriage was common. Economic imbalance, however, emerged in the seventies when Croatia and Slovenia in the North became more prosperous than rural Serbia, Macedonia and Kosovo. In 1991, war broke out when the Yugoslav army attacked Slovenia, which decided to pull out of the federation. After a few weeks, Croatia followed by starting a war against its rebellious Serb minority, and subsequently, Bosnia voted for independence in March 1992, which resulted in war being declared on the state by the Serbs of Bosnia. In January 1993 there were severe fights between the Bosnian Croats and Muslims. Two years later, a war in and over Kosovo started. All these war activities were stopped when NATO troops attacked the Serbian forces in the autumn of 1995, and Serbia itself in the spring of 1999.

The Serb-Croat and Serb-Bosnian wars took a terrible toll on their peoples. Judt observes that ethnic cleansing was engaged in by all sides, but that "Serb forces were the worst offenders" (p. 675). Three million people from Yugoslavia sought refuge abroad, most of them got asylum in Germany, Austria and the Scandinavian countries. The failure to put an end to the tragedy in Yugoslavia resulted from weak strategic decisions taken by both the United Nations and the European Union. Representatives of the UN "spent most of their time blocking any decisive military action against the worst offenders" (p. 683). The EU was divided: France was reluctant to blame Serbia for the course of events, the Netherlands vetoed NATO strikes on the Bosnian Serbs until all Dutch soldiers were safely out of the country. The situation changed when seven weeks after the fall of Srebrenica the US engaged and President Clinton authorized a serious bombing campaign on the Serbs at the end of August 1995. This resulted in the peace-agreement, signed in Dayton, USA, on December 21st 1995, which included a complicated system of governance for Bosnia.

In the case of Srebrenica, after almost two decades, it still is demanding to distinguish the social and political facts from imaginary realities and personal stories. What was seen and witnessed was influenced by one's position, presuppositions and background, or tinged by a lack of insight on the part of those unfamiliar with the specific historical conditions. Stories, as Schaffer and Smith observe, "emerge in the midst of complex and uneven relationships of power" (p. 5). The fall of Srebrenica is a painful memory in contemporary European history, and in Dutch history 
in particular. This became clear in a documentary broadcast on Dutch public television, ${ }^{3}$ in which 16 former soldiers of Dutchbat III were interviewed, and not only showed anger and frustration, but also complained about the lack of knowledge on the part of the general public about what exactly happened in the summer of 1995 . The most fascinating story in this television program, was told by soldier Rob Zomer, who had gone back to Srebrenica in 2008, and a year later built a house overlooking the valley. When the interviewer asked him if he was in a sense looking down "on his guilt", Zomer denied this. He pointed out that the people from the region had welcomed him on his return and thanked him for his efforts and help in 1995. And yet, he does not seem convinced that he did enough that summer. Like quite a few others in his former battalion, he is still suffering from PTSS (Post Traumatic Stress Syndrome). It seems he has not been able to round off his own narrative of what happened so many years ago.

In this paper I will scrutinize some of the stories on Srebrenica and argue that the imaginative dimension of telling a personal story opens up the potential of speaking in an authentic voice. My aim is to rethink the claim on a testimony of real facts. Not objectification, but the ability of connecting reality, memories, emotions and images, of placing oneself in a narrative of others (and vice versa), and constructing the paradox of a fictionary truth, opens a paradigm in life narrative from which the collective story can emerge. If we want to comprehend this particular part of contemporary European history, we have to listen to the various voices constructing their own stories in their own way. "If I tell it myself, the story is completely different", Liesbeth, a former Dutchbat soldier, says in the television program.

This paper unfolds as follows. First, I will briefly discuss theoretical approaches to life writing. The next section explores three exemplary narratives: an autobiographical testimony by a Muslim refugee who lived in the Srebrenica enclave from 1992-1995, a more comprehensive documentary written by an American journalist, and an art-project on photographs and short autobiographies characterizing 68 Dutchbat soldiers. All stories represent and evoke experiences and mark polyphony in regard to the historical narrative of July 1995. In the last part I argue that not verification but imagination contributes to an understanding of the narrative of Srebrenica as one of the significant stories of contemporary Europe.

\section{THEORETICAL FRAME}

Life narrative is the umbrella term for stories representing a life. The concept includes autobiography as a retrospective narrative and is also 
used to cover more heterogeneous self-referential and self-reflexive practices (Smith and Watson 2010, p. 4). ${ }^{4}$ Studies of life narrative focus on the ethical, referential, imaginary and cognitive dimensions of a story. This implies more than the idea that a real person speaks as an autonomous subject, as Philippe Lejeune suggested. The Lejeune position on the autonomous speaking subject blocks the understanding of identity as relational and does not pay enough attention to the hybrid discourses in which it finds expression (Eakin 1999, p. 58). The story of the self is interwoven with stories of other selves, told of and by other subjects. All the narratives examined here, indeed are stories of relational lives taking place in specific social communities. The stories are embedded in other stories, which in turn are embedded in yet other stories, and so on. This makes the teller of one story a character or voice in the story of another. Consequently, storytellers are part of a shared context of meanings that they do not (only) create themselves (Guignon 2004, p. 127).

Because of the relatedness of stories, it is difficult to decide upon the truth of any one story, since no speaker has the final representation at their disposal of all the perspectives and historical and political facts. No storyteller is capable of expressing the exact truth in language. Although the intention to tell the truth often is regarded as a guarantee of autobiographical veracity and sincerity (Marcus 1994, p. 3), we have to be aware that intention as such is a problematic notion when dealing with (traumatic) testimonies. In a testimony the storyteller constructs a narration in which a narrated ' $\mathrm{I}$ ' expresses what has happened, but the narrative process as such always complicates and colors the facts, events and experiences. Smith and Watson (2012) observe that four typical 'I' formations can be distinguished in testimonies, namely a "composite I", a "coalitional I", a "translated I" and a "negotiable I". These rhetorical modes are connected to five "metrics of authenticity". ${ }^{5}$ In regard to the composite 'I' and the coalitional ' $I$ ', a first-person narrator is produced by an ensemble of actors, including addressees within the narrative. In the translated and negotiable ' $\mathrm{I}$ ', a collective subject is engaged in telling the narrative, and the process of telling "as an act of self-examination goes beyond the confession of victimage to the creation of a subject with a degree of agency about his own story" (p. 609). Thus, different acts of witnessing are constructed in a narrative. In the cases considered in this paper, in particular in the first two, these formations will be used as well as nuanced.

In Reading Autobiography, sixty genres of life writing are distinguished. From the point of view of the texts on Srebrenica collected here, the most relevant distinctions in life narrative are: auto-ethnography (collectivized and situated life writing in which the bios of autobiography is replaced by ethnos or social group), collaborative life writing (production of 
an autobiographical text told by more than one person), ethnic life narrative (narrative emergent in ethnic communities negotiating ethnic identity around multiple pasts), genealogical story (authenticating identity by constructing a family tree of descent), survivor narrative (narratives on traumatic, abusive or genocidal experiences) and war memoir (military life writing). Making a distinction between genres or discourses is relevant because of the emphasis on different features and subject positions in telling and writing. The genres indeed can be used as frames or lenses through which we start our reading. On the other hand, all the genres are to a certain extent fluid. Forms of life writing are often hybrid and as such offer a complex mixture of modes of mediating political, ethical, historical and aesthetic discourses.

Life narratives on Srebrenica belong to the field of trauma studies or rights discourse (LaCapra 2001, Ricoeur 2004, Schaffer and Smith 2004), since in the stories many voices speak of the cruelties of ethnic cleansing, of personal grief and failure, of the tragedy of historical developments over decades, and the taking of wrong decisions by political and military leaders. The texts discussed, however, should also be considered as artistic texts. They are a literary testimony, a chronicle and a photography project, each of them with a certain aesthetic potential, artifacts with a singular expression. French philosopher Jacques Rancière rightly suggested that the relatedness of aesthetics and politics is more than the representation of historical events in an aesthetic form. ${ }^{6}$ It is in the autonomous realm of literature or art that politics is encapsulated, just as it is in the language of a documentary on everyday life issues, that an aesthetic dimension can appear, mainly as a semiotic potential to recognize an ambiguous perspective in real and imagined phenomena. I am particularly interested in this ambiguous and imaginative perspective of life writing. This ties in with W. Dilthey's conception of autobiographical discourse in the context of historiography, emphasizing that the artist seeks the connecting threads in the narrative of life, s/he creates connections and puts them into words and images. The lived experience (Erlebnis) and the representation of facts and states of affairs (Erfahrung) have to be distinguished as developmental structures of historical understanding (Marcus 1994, p. 138).

In consequence, referentiality should not be the central topic in discussions on life narrative. What is more relevant is the issue of the authenticity of voice, which validates claims as truthful or reliable even when things did not happen in reality exactly as they are told. Voice as a rhetorical act validates an idea, conviction or meaning, even when there is no objective proof. The Bakhtinian notion of voice, sets apart social voice from individual voice (Bakhtin 1981, Felski 2008). In Bakhtin's terms, voice is never neutral, but always projects a particular perspective and 
authority. In relation to this, I argue that life writing can be regarded as a discourse in which conflicting voices can be observed. Voices often are double-tongued, speaking for a self and for others, and even speaking to a previous version of a self or about things that one has forgotten. Polyphony marks the social structure of power and inequality at work in the stories told.

\section{STORIES OF MUSLIM CITIZENS}

In light of the contradictory forces of history, politics and culture in the former Yugoslavia, we can ask how the collective narrative of Srebrenica can be constructed, which stories are told by whom, whose voices are heard and how the ideas and convictions of different speakers intersect. How do separate stories construct a memory of this European locus? These questions are fundamental in the exploration of the two examples of life narrative I discuss in this section.

The first story is the narrative of an eyewitness, the Muslim citizen Emir Suljagic, published as Postcards from the Grave (2005). ${ }^{7}$ Suljagic (b. 1975), currently working as a journalist in Sarajevo, experienced the siege of Srebrenica as an adolescent and tells about his experiences in what might be called a survivor narrative. He was seventeen years old in the spring of 1992, when he arrived in the enclave, with some ten thousand others fleeing from the Serbian troops. He stayed in the valley until the end, July 1995, working as a translator for the UN. This testimony thus voices the story of a former, younger self - and also represents the stories of others who are not able to speak anymore. This first person narration, or "character narration" (Phelan 2005, p. 214), is paradoxical, since from the beginning of the story we are aware of the complexity of the narrator's voice, the 'I' is both narrator and character, speaking for himself as well as for others, speaking the truth as well as deliberately altering it:

I survived. My name could be Muhamed, Ibrahim or Isak, that doesn't make a difference, I survived and many others didn't. I survived the same way they died. There's no difference between their deaths and my survival because I'm living on in a world that is forever and irrevocably marked by their deaths. I am from Srebrenica. I am really from somewhere else, but I have chosen to be from Srebrenica. It's the only place I dare to be from, the same way it was the only place I dared to go to in a time where I couldn't go anywhere else. (p. 13) ${ }^{8}$

The narrator speaks in his own voice, representing others who have died. Using the frame of Smith and Watson (2012), this 'I' narrator can be 
characterized as 'coalitional 'I', since "collaborative production (...) is foregrounded: and the multiple voices of the collaborative I are both distinguished and, at times, blended" (p. 605). The narrator literally takes up the other's names, thus identifying himself as multiple individuals, but then immediately also emphasizing that he was more lucky than others. He is the one who is capable to tell the story. This testimony is not written, however, from the "subject position of a victim to be rescued" (p. 600), this subject positions himself as a critical spectator, who was there observing all the other positions. He was born in a village elsewhere in the region, but in the beginning of his testimony, he chooses to be "from Srebrenica", redefining and articulating his origin and thus identity. And in doing so, he underlines the potential of narration: facts can be changed and reorganized. The opening of the text instantly makes clear that the experiences described have happened, but not necessarily exactly as described and experienced by this particular narrator.

In his narrative Suljagic makes the events come back to life. ${ }^{9}$ Although he is eager to tell the story "of everyone who was there and survived or not", the narrator realizes that speaking for others is not always possible. How to express, for instance, in exact terms what happened on July 11, 1995 when thousands of scared refugees gathered on the Dutch compound in Potocari, watched by Mladic's men, and ignored by the commanders of the base? Suljagic only has his own point of view:

I was in Potocari at the time, at the Dutch base, where I was working as an
interpreter for the three-men team of UN observers. The betrayal I have seen
is different from the betrayal seen by the survivors of the massacre. (...) What
I saw was a cold, bureaucratic lack of interest, betrayal perpetrated by people
with an education, intelligent people by all standards. People who in those
days lacked the courage or the will to be just that. (p. 151) 10

The narrator stresses that different forms of treachery were committed in the heat of July 1995, and focusing on his particular perspective, critiques a Dutch stereotype: order is important, more than responsibility. The Dutch commanders at the time lacked courage, and found the maintenance of civil service and bureaucracy more important than the survival of indigenous Muslims. The Bosnian Serbs required the registration of everyone who was officially working on the compound, and Suljagic himself (the 'I' narrator) tried to list the brother of his colleague Hasan as a "cleaner" to save him from deportation. But commander Robert Franken did not accept this and highlighted the name of the boy with a pink marker: he "crossed out the name, a human being, a life" (p. 174). ${ }^{11}$ The registration is done with indifference, and huge consequences. The succinctness of narrator's voice is rather cynical. 
As said, Suljagic's testimony can be regarded as a survivor narrative, offering the perspective from someone who remained when others were deported, and who is in retrospect able to report on what happened and how it happened. Truth, however, is a local issue, something not transferable. The truth of someone being there on the Dutch base was different from the truth of the people at the other side of the fence, or the ones hiding in buildings in the enclave. No one from outside Srebrenica could really have understood what it felt like to live in that overcrowded place, where one - despite everything - tried to behave normally. Suljagic describes how people tried to keep up living "an ordinary life" in which electricity was generated with self-constructed devices, and cinemas were built in houses with a still functioning TV set and some DVDs. And there even was a newspaper, the Glas Srebrenice, appearing for three years in twenty typescript copies made on the backs of used official documents. The newspaper was passed on between friends and relatives and did not offer any news, but the illusion of the possibility of a form of intellectual life.

Suljagic's testimony voices the experiences and emotions of his younger self and represents the story of common Muslim people, many of them no longer alive. What is relevant to emphasize here, is that taking up the voice of others who cannot speak anymore, is an act of imagination: the narrator does not know what they would have said and described, if they would still be alive today. Suljagic speaks for them, in a very particular voice, when condemning the acts of Dutchbat, criticizing the indifference and lack of courage of the military leaders. As such, this coalitional narrator, is not really a "blended we", as Smith and Watson described it, but represents different voices - polyphony in the Bakhtinian sense - at the same time. Suljagic is not (only) the victim, but also a survivor, he uses the social discourse of the local Muslims, as well as utters fierce critique on the lack of responsibility of the Dutchbatters who could have make a difference.

A second text on what took place in Srebrenica in 1995, is Blood and Vengeance (1998), a chronicle written by Chuck Sudetic, an American journalist of Croatian and Irish descent. The narrator position in this text is more hybrid. The text gives voice to several members of a Muslim family, the Celiks, and also represents the explicit point of view and experiences of Sudetic himself. The book can be characterized as a genealogical narrative or collaborative narrative. Parts of it are written as eyewitness account, from the point of view of an 'I' narrator reporting on what happened, other parts are written from the distance of an omniscient narrator, when the journalist brings in historical information on the region and on contemporary politics. The narrative not only tells about the events of the 
1990s, but focuses on the longer history and social context of this family and region. We are told where the members of the family came from, what they did for a living, who married whom and which children were born. Thus, the ethnographic, social and historical context of a Muslim family from eastern Bosnia is depicted. This representative family story shows how social class and ethnic boundaries influenced the general narrative of the Srebrenica area, where there was almost no industry and consequently no prosperity. From the 15th century onwards, the region was troubled by contesting forces: Ottoman versus Serbian; Istanbul versus Vienna; feudal rulers versus poor peasants.

Sudetic not only goes into the history of the land and that of the Celik family, he also presents a meticulous report of political events and decisions taken in the course of 1995 before the fall of the enclave. In some parts of this account, he deliberately writes himself in as eyewitness, as the journalist present at the time. This, obviously, gives the text the status of a particular testimony; such as when Sudetic describes how a convoy of trucks loaded with people arrives in the Muslim safe area Tuzla: "all I did was scribble some details into my notebook: truck beds coated with filth and urine; people stinking of sweat, shit, woodsmoke, and death; someone said this; someone else said that" (p. 187). Impressions and details make up the particular voice of the narrator looking back on himself as a reporter. He observed and kept a distance trying to write an objective account, and often just reproducing the words of others:

\footnotetext{
"The situation in Bosnia is unmanageable,"Janvier ${ }^{12}$ told the council members, explaining that the four hundred or so Dutch troops in Srebrenica, for example, could neither defend the enclave's forty thousand people nor deter attacks against them, especially since Muslim soldiers were operating out of the safe area. "Missions that put UNPROFOR's troops at great risk, such as deployment to the eastern enclaves ... should be dropped". (p. 255)
}

The narrator as journalist reproduces the exact words of politicians and the military leaders responsible. By repeating these words, the strategic decisions taken seem to be less professional than one would expect from leaders in power. Sudetic as such affirms the narrative of the weak strategic negotiations by both the United Nations and the European Union. By blending the perspectives of narration, the configuration of a "translated I", as Smith and Watson discussed, becomes clear. The 'I' is translated from "local to international contexts to distill the experience of a collective subject engaged in a process of immersion in conflict and dehumanization of self and others" (p. 609). Sudetic structures the text, reproduces multiple voices and social discourses (as said, Bakhtin's 
concept of polyphony or heteroglossia is relevant here) and thus reveals power mechanisms. This becomes particularly clear when he reports on the mounting tension in the enclave when Mladic tightened his grip on the area and Muslim officials subsequently asked the Dutch Lieutenant Colonel Ton Karremans to keep his men away from the areas under Muslim control. But Karremans refused to comply with this request and Muslim commander Tursunovic "seized a hundred Dutch soldiers and held them captive for four days" (p. 256). The safe area obviously was more an area of contesting forces than one of "peace keeping" and it is this complicated pattern of actions and reactions that Sudetic sketches meticulously. ${ }^{13}$ The narrative takes place in a geopolitical space in which subjects found themselves in conflict situations, and borders had to be negotiated. The stories of individuals were part of the stories of material surroundings and limitations: region, nations, continents, and global politics. Sudetic consciously switches from accounts of political and military events to micro storia, such as the scene of the birth of a boy, a few days after his mother is deported from Srebrenica: "Nehrudin Halilovic was born two days earlier than expected, at four in the morning of Saturday, July 15, 1995. Sanela took him to a tent in a refugee camp at Tuzla airport. The baby's father and both of his grandfathers might still have been alive" (p. 314). By switching from macro (politics) to micro (family) level, from private to public voices, from the newborn baby to the grandfather about to be executed, the narration forces the reader to be aware of the complexity of the situation and the different points of view. Sudetic, as we would expect from a journalist, tries to give as much information and represents as many perspectives as possible. And again, it is important to notice that he also deliberately uses imagination when he cannot witness all the events taking place. Since no viewers were allowed to watch the executions, he has to imagine them, in order to make his story complete. Therefore, he has to suggest how Muslim men are shot on a soccer field near the village of Krizevacke Njive:

As the trucks revved their engines, half a dozen soldiers opened fire into the Muslims' backs. Their legs gave way. They fell to the earth. The executioners searched for movement among the tangle of bodies. The twitch of a leg brought a bullet through the head. (...) The father, both grandfathers, and an uncle of Sanela's infant son, Nehrudin, had disappeared. It is not unlikely that they all died on the first day of Nehrudin's life. (pp. 316-317)

This scene is imagined, the narrator - not using an explicit 'I' configuration here but taking a omniscient position - has to keep distance from what he is telling. The journalist himself was not there. But he makes the scene convincing and helps the reader picturing the events: it was 
on local fields, only a few kilometers away from the town, that the men were executed. The narrator suggests what has happened, since exact information on the death on so many men is lacking. By pointing at "the father, both grandfathers, and an uncle" of the baby Nehrudin, however, Sudetic personalizes the narrative and shows the tragedy from a nearby perspective.

"Facts are subversive", historian Timothy Garton Ash wrote in an introduction to articles on the European history of the present (2009, p. xi), and that is exactly what we notice here: the facts are often incomprehensible and not reproducible. How to represent death when nobody survived? The narrator has to imagine the dead, if he chooses to tell the complete story from the perspective of common Muslim men, who have been lost, and whose disappearance was not noticed by any officials or news reporters. He represents the process of dying by focalizing the newborn baby, the survivor, the one who just entered life in these cruel circumstances. While facts are subversive, the truth is encapsulated; enclosed in the certainty of the murder of almost 7,500 men and boys in deserted villages, schools and on open fields; in the promise of Nato-F16s who did not get there in time; in the not taking any action at all by the government of British Prime-Minister John Major, or in the decision to do something that American president Bill Clinton did take, obviously with an eye to his re-election. Everyone, as Sudetic shows in his chronicle, focused on his own facts, believed in his own truth, stuck to his own convictions and political agenda.

\section{STORIES OF THE DUTCHBAT MILITARY - AN ART PROJECT}

Telling a story on what happened in July 1995 is important not only for the Muslims of Srebrenica, but also for the members of Dutchbat III, as became clear in the television program I referred to in the introduction of this paper. Constructing a narrative and choosing a perspective can be therapeutic, or at least a step toward understanding the self in the context of decisions taken. An impressive project of photographs and short autobiographies of members of Dutchbat, will be discussed in this paragraph, again with the question in mind how the separate stories help to construct a memory of this European locus.

Photographer Friso Keuris ${ }^{14}$ (b. 1963) created "Dutchbat III" a series of 68 portraits of former soldiers of the UN battalion who witnessed the drama of Srebrenica in 1995. After finishing the project, it resulted in a solo exhibition in The Hague and a book publication. The latter is used here. The personal stories next to each portrait in black and white, are written by Keuris who spoke with the men and women for hours. ${ }^{15}$ The 
photographer in this case thus mediates the personal stories. The artist intervenes, so to say, in the narratives of Dutchbat, he gives them voice. The collection of photographs and texts, can be considered a form of life narrative as war memoir, - although the Dutch officially were not at war with the Serbian forces.

It is not a surprise that the members of Dutchbat III feel anger, frustration and shame over what happened, and it is interesting to observe how their short autobiographies emphasize various detailed facts and feelings. These are transparent stories, in the sense of the events represented, though it is not always easy to make out what exactly is expressed. The words often seem to encapsulate disturbing emotions. Since the photographs were made in the period 2006-2010, all portraits are showing the men and women 10-15 years later, and it is relevant to realize how young most of them have been at the time. Some reflect on their position in the context of the political and military strategies, others tell more personal stories. Some came to Bosnia in the context of compulsory military service, others had chosen for "adventure" or "the money". In the mean time some of them have built up a normal life, while others still have the feeling "that everything went wrong" (p. 58) and have difficulties in going on with their lives. Keuris portrayed them all in black and white in clear light. The photographs can be characterized as minimalistic, due to the lack of decoration. The overall impression is that the heads are strong, while the words expose more vulnerability.

Paramedic soldier André Dekker (b. 1972), 23 in the summer of 1995, is portrayed with a serious expression on his face, and opens his story by telling about Muslim children, visiting the observation post (see his portrait in figure 1). He explains that he still feels the anger, fear and powerlessness. His words show how the young soldier had to make choices in the heat of the moment:

\begin{abstract}
After the fall of Srebrenica we drove in an armored vehicle alongside the refugees heading in the direction of Potocari. Our vehicle was full. Yet people tried to get in. It was terrible, but during the trip I had to push off a woman with a young child. We really were filled to capacity. I've been able to be of service, I helped many wounded people and that way the mission gave me satisfaction. But it's been the last mission of this kind I'll ever go on. (p. 26) ${ }^{16}$
\end{abstract}

The soldier is capable of critical reflection on personal memories. Though the choices made were difficult, the conclusion is that he has been of service, that he was able to help the wounded. He is not portrayed as a hero, he looks still young, and is earnest in the way he attentively observes the viewer.

Although the political and military context did not offer the Dutchbat company alternative choices for responding to, or even resisting 


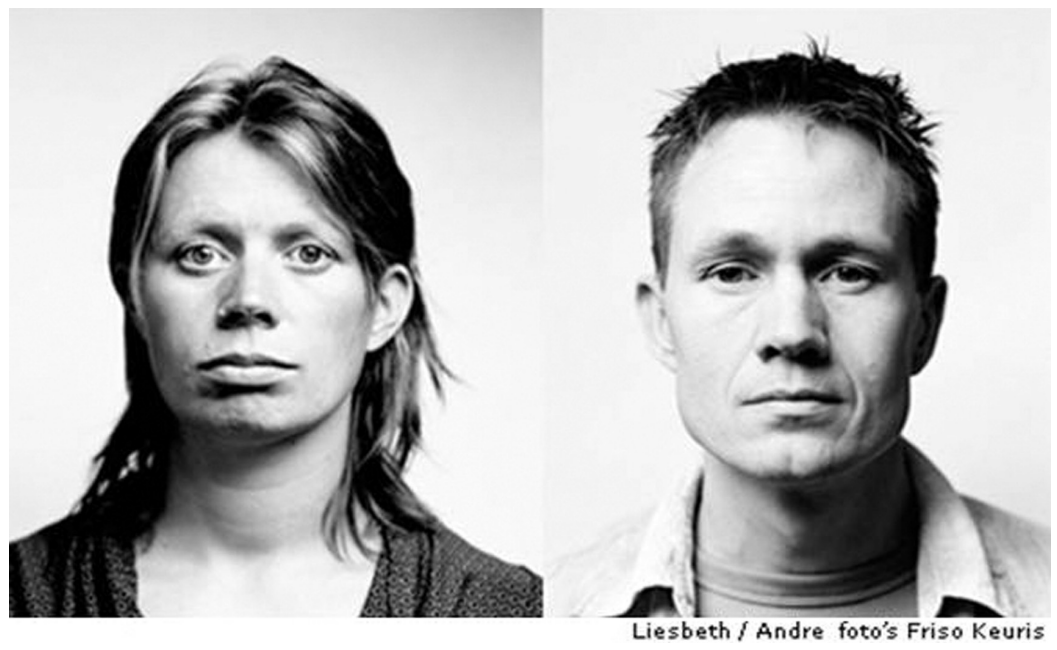

Figure 1. Portraits of Liesbeth Beukeboom and Andre Dekker.

Mladic's troops, some men realized that they had a responsibility and made an explicit link with the historical European context. This is what Bert Kleen, sergeant, infantry soldier and explorer explains. His portrait shows a strong man with sharp open eyes:

During the deportation of Muslims in buses, we had to assist in the separation of the people. It was total chaos. Two Dutch lieutenants were quarreling because one of them did not agree with our supporting the Serbs. For him, these were Nazi practices we were made to take part in. When we left I was so frustrated I crushed all my gear under my boots. I wanted to leave nothing behind for the Serbs. (p. 38) ${ }^{17}$

Again the explanation of what happened expresses frustration and emotion. This sergeant however, also is able to put things in a historical perspective. He makes clear that they knew what was going on: "Nazi practices" (p. 38). The historical echo referring to images of WW II comes back in the stories of other members of Dutchbat, for instance in the one told by female soldier and truck driver Liesbeth Beukeboom (see her portrait in figure 1):

We had to transport Muslim women who had worked in our compound. They walked into the truck on wooden boards. It did not take long before it 
felt like we were transporting livestock. By thinking of them that way, I was protecting myself. We just turned the switch. (p. 106). ${ }^{18}$

The portrait shows a woman with impressive eyes, someone looking serious into the camera. In July 1995 she was only 19 years old. She tells that she had a "short women contract" and submitted to the army during a presentation day of the UN. She was sent out to the former Yugoslavia, and realized immediately that the "reality did not match my expectations" (p. 106). The reality indeed was harsh: the Dutch had to deport Muslim women in a truck, and obviously, an ordinary young woman from a Dutch province could not have prepared mentally to doing something like this. That is no doubt the reason why she imagines that these women can be considered as animals. This was a mechanism of self support: "By thinking of them that way, I was protecting myself”. Switching off one's emotions, no longer thinking of the other as a human being like oneself, is a typical strategy discussed in trauma studies (LaCapra 2001, Arendt 2005 [1963]). ${ }^{19}$ It involves the blockage of affect, the decision to be an observer, rather than someone with agency. The separation between "we" and "they" is consciously made; it is we/us the Dutch military versus they/ them the Muslim victims. But the distinction is also used to characterize the we/us as witnesses in Srebrenica, versus they/them at home in the Netherlands criticizing the Dutchbat actions from behind a TV screen. This frustration is something we can pick up from the story of infantry soldier Rob Zomer, again someone portrayed with open eyes and short haircut, the typical tough guy:

We ended up walking along with the refugees from Srebrenica to Potocari. That's a 3 to 4 -mile walk. It was one big stream. I helped the refugees. We tried to get the older people who couldn't or didn't want to walk anymore to come along. There was so much going on there that half the time I was hardly aware of what was happening. When I got back home the first thing I heard was that I had 'aided in the killing of men'. I hit the guy who yelled this straight in the jaw. You can't blame the Dutchbat soldiers for the Bosnian men taking another route. It was them who were on the run. The way I felt it, we'd actually done more than we could be expected to do. We were punished by the people who were back home in Holland, by those who were at a safe distance. (p. 138) $)^{20}$

As in the autobiographical sketches of the other soldiers a double-voicedness emerges here. The switch from "I" to "we" is significant. The narrator uses "we" in the neutral, more positive sense as in "we ended up walking along with the refugees"; and in doing so he emphasizes the companionship. This is a representation of the situation, as well as an illustration 
of the ideas and feelings of the speaker. What he expresses is: I am not responsible for this on my own, we did it together. But then he continues: "I helped the refugees", "We tried to get people to come along", "I was hardly aware of what was happening", and in this it becomes clear that he somehow lost the feeling of companionship in the heat of the events. His own voice is not synchronous with the voices of others.

When Rob Zomer came back to Holland, he was immediately accused of killing people: "I had aided in the killing of men". Here, we recognize the voice of an outsider, someone beyond the companion- "we" who were with him at the time. Subsequently, the voice takes a political and distanciating turn: "You can't blame the Dutchbat soldiers for the Bosnian men taking another route. It was them who were on the run". This is, of course, an understandable but very one-sided take on what happened. It is a response to the accusation that Dutchbat acted cowardly, and did not really feel responsible for the Muslim refugees in Srebrenica. In the end, the narrator asserts that he has accepted the situation: "We'd actually done more than we could be expected to do. We were punished by the people who $(. .$.$) were at a safe distance". But when we realize that the man speak-$ ing here is the same Rob Zomer who appeared in the television show and told that in 2009 he has built a house in the mountains surrounding Srebrenica, we realize that the last words of his narrative could be ambiguous. How can one be so sure that one has done more than could be expected?

Enclosed in the exhibition catalog is a DVD with private videos shot by Dutchbat soldiers showing the impossibility of the mission, the mess in the compound, the poor facilities, the poverty of the people. A similar picture of shortage and chaos emerges from the life narratives of the soldiers: weapons did not work, the strategic position of the compound was hopeless with Serbian snipers looking down on them from the surrounding mountains, and there was a lack of fresh food supplies. "On our observation post, at one moment we only ate cookies with Thai sauce" (p. 104) soldier Kevin Tjon-A-Joe tells. But then, driving one day through another part of Bosnia they saw "how normal life continued. There was shopping to be done. And plants to be watered. We entered a bungalow park" (p. 104). Corporal Felix Mol affirms the lack of food in the Dutch camp: "There were no supplies at all", he stresses, "And even if we had had 500 or 700 men more, what were we going to do against this superior force of Bosnian Serbs, all doped to the gills, with all the equipment they needed, we were never going to hold them back" (p. 68). ${ }^{21}$ The man realized that they were not properly equipped for the job, they had no facilities at all to carry out the keeping peace mission in the enclave. This certainly is the impression we get from the official NIOD report published under supervision of professor Hans Blom in April 2002 after an investigation of eight 
years: "Dutchbat arrived in 1994 in an enclave characterized by severely complicated relations and was ill-prepared for the situation. (...) This resulted in an inward-looking mentality and caused negative stereotypical opinions to be reinforced. Dutchbat often was quite negative about the people in the enclave, but cannot be accused of deliberately adopting an anti-Muslim attitude". 22

The stories and portraits of Dutchbat III offer a noteworthy documentary of the events in Srebrenica in 1995, in particular because the narratives are personal impressions, rather than complete stories. Friso Keuris, the artist himself, is invisible, but obviously brought all the stories and photographs together. The stories are all testimonies, which in the compilation of the 68 separate stories form a collective project. We observe the heads and hear the voices of mainly young men and women, at the time inexperienced and badly informed on the conflicts in the region. The frustration of their situation, without supplies and real political and international support, shows that a contemporary variant on the "banality of evil" was found in chaos and non-preparation of the UN mission. This can be considered the message of the art project.

\section{CONCLUSION: POLYPHONY, IMAGINATION AND AUTHENTICITY}

From the life stories discussed in this paper, a polyphony of voices emerges. We must listen to these voices against the backdrop of what we know about this dramatic period in contemporary European history. Polyphony or multivocality as such assumes social structures of power and inequality (Blommaert 2005, p. 41). The Muslim refugees in the enclave were powerless, just as, in a certain way, were the young soldiers from Dutchbat III. Each individual voice, however, has to construct and reflect upon his own story in the context of the hierarchical structures, using his imagination to reflect also on the position of others. ${ }^{23}$ My point is, that without imagination, without a creative ability to visualize, one is unable to really understand the events, the acts and consequences. Suljagic wrote the testimony of his own adolescence, giving voice to his younger self and to non-survivors. He imagined himself as coming from Srebrenica, thus taking and visualizing a position in the heart of the tragedy. Sudetic structured his journalistic chronicle both as 'I'-narrator and from an omniscient perspective, and as such represented the voices of a typical Muslim family. He imagined their lives, as well as how the executions on the men took place. Photographer Keuris portrayed the Dutchbat men and women, and gave them voice by letting them comment on their own 
position. Storytellers, as well as the artist collecting the stories, as well as the audience watching the portraits, use imagination to envisage the events in this specific locus. Most pregnant, in this context, was the voice of a woman realizing that she deliberately had imagined the others as non-human beings.

Various voices transpire from these life narratives. Different acts of witnessing are constructed, and, as I like to emphasize in conclusion, various acts of authentic speaking are revealed. But in what way are voices authentic? And how does this material differ from the testimonies discussed by Smith and Watson (2012)? My observation from analyzing and discussing these specific narratives, is that authenticity should not be understood as eigen or original but is related to the social dimension in which a voice manifests itself (Bruner 2002, Taylor 1991). Every authentic voice as self is a res publica, something created in a public space, in the company and social structure of others. Often, the one who is speaking about his own feelings and experience, has to picture what the other experienced or felt, in order to make his own story fit in the general narrative. As soon as we recognize the multiplicity of voices, and accept that each voice is embedded in other stories as a social construction, we realize that authenticity involves more than a particular version of the truth, and more even than the intention to speak the truth. Even truth, after all, is a relational concept, it needs to be created and re-told. "I knew hundreds of similar stories, and after the first dozen or so they were hardly new", Sudetic writes (1998, p. xxxiii), underlining that the true perspective on war can only be grasped by creating various portraits of people, of perpetrators and victims, of separate and related individuals without losing sight on the particularity of each voice in the context of the other voices. The frustration of the UN Blue Berets is connected to the trauma of the Muslim women deported in buses, and to the disappearance of the men who did not survive. What is important in the words of people who witnessed and experienced, is not only what they wanted to express, but also what they made possible in regard to the construction of images, discourses and counter-stories. This becomes particularly clear in the art project of Keuris; without intervening in the stories, the photographer both visualizes the self-esteem and vulnerability of the storytellers, while the black-and-white portraits establish that the words are not that black-andwhite in the sense of clarity and unambiguousness. The various life narratives show how the Dutchbat storytellers wanted to leave a sign of their lives and of those of other people in that place, even when these others were pushed away. "I protected myself", the female soldier explained, by thinking of the other women as cattle and thus avoiding at the time moral engagement. This (brave) analysis, anno 2010, obviously is an act of self-knowledge, of imposing oneself in a particular personal story and realizing the impact of the not-having seen the other women as women. 
In conclusion, I like to emphasize that authenticity in the context of the Srebrenica stories has to be understood not as an honest way of speaking, but as a moral principle relating the self to the community. Political philosopher Charles Taylor discussed this notion of authenticity in the context of two effects of modernity: relativism and nihilism on the one side, and selfcelebration and self-fashioning on the other. For Taylor, it is not individualism as self-fulfillment or self-realization that is important, but authenticity as responsibilization. As he writes: "Authenticity is clearly self-referential: this has to be my orientation. But this doesn't mean that on another level the content must be self-referential: that my goals must express or fulfill my desires or aspirations, as against something that stands beyond these" (p. 82). Taylor describes how authenticity "connects us to a wider whole" (p. 91) and marks a "sense of belonging". In this line, I understand belonging as belonging to a common story, a collective narrative, into which various stories are interwoven. The aim of all the stories told, is that somehow a community will be constructed in which one can listen to all the different voices.

Srebrenica definitely is part of the European history of the present and the stories of the destroyed enclave have to be kept in memory, in ritual commemorations, such as the Dutch May 4th Remembrance Day, commemorating the victims of WW II, as well as in history lessons in school. To keep in memory that in Europe, 50 years after World War II, a massacre could take place. Hearing the separate voices not paid attention to in regular news coverage at the time, alerts us that we have to use our imagination to visualize places not seen or reported upon by the international media. We have to be aware of the voices on the micro-level of history.

\section{WORKS CITED}

Agamben, Giorgio. Remnants of Auschwitz, The Witness and the Archive, Translated by Daniel Heller-Roazen. New York: Zone Books, 2002. Print.

Arendt, Hannah. Eichmann in Jerusalem, De banaliteit van het kwaad. Vertaald door W.J.P. Scholz, met een voorwoord van Ido de Haan. Amsterdam / Antwerpen: Uitgeverij Atlas, 2005. Print.

Bakhtin, Mikhail Mikhailovich. The Dialogic Imagination, Four Essays, Edited by Michael Holquist, Translated by Caryl Emerson and Michael Holquist. Austin: University of Texas Press, 2008 [1981].

Blommaert, Jan. The Sociolinguistics of Globalization. Cambridge: Cambridge UP, 2005. Print.

Boom, Joeri. "Schuilen achter het OM, De zaak Srebrenica". In: De Groene Amsterdammer, 2107-2010. See: < http://www.groene.nl/artikel/135198> [Accessed on 21 October 2013] Web.

Bruner, Jerome. Making Stories, Law, Literature, Life. New York: Farrar, Straus and Giroux, 2002. Print.

Eakin, Paul John. How our Lives become Stories - Making Selves. Ithaca and London: Cornell U P, 1999. Print.

Felski, Rita. Uses of Literature. Oxford: Blackwell, 2008. Print. 
Garton Ash, Timothy. Facts are Subversive, Political Writing from a Decade without a Name. London: Atlantic Books, 2009. Print.

Guignon, Charls. On Being Authentic. London and New York: Routledge, 2004. Print.

Habermas, J. Europe: The Faltering Project. Cambridge: Polity Press, 2009.

Honig, Jan Willem and Norbert Both. Srebrenica, Record of a War Crime. London: Penguin Books, 1996. Print.

Judt, Tony. Postwar, A History of Europe since 1945. London: Pimlico, 2007. [2005]. Print.

Karremans, Thom. Srebrenica Who Cares? Een puzzel van de werkelijkheid. Nieuwegein: Arko Uitgeverij, 1998. Print.

Keuris, Friso. Dutchbat III, Getuigenissen na Srebrenica. Zwolle: d'jongeHond, 2010. Print.

LaCapra, Dominick. Writing History, Writing Trauma. Baltimore and London: The Johns Hopkins U P, 2001. Print.

Marcus, Laura. Auto/biographical discourses, Theory, Criticism, Practice. Manchester: Manchester U P, 1994. Print.

Niod Rapport Srebrenica, Perssamenvatting. Web. <http://www.vredesnaam.com/NIOD/ NIOD2.html.> [Accessed on 21 October 2013].

Phelan, James. Living to Tell About it. A Rhetoric and Ethics of Character Narration. Ithaca and London: Cornell U P, 2005. Print.

Rancière, Jacques. Dissensus, On Politics and Aesthetics. London and New York: Continuum International Publishing Group Ltd., 2010. Print.

Ricoeur, Paul. Memory, History, Forgetting. Translated by Kathleen Blamey and David Pellauer. Chicago and London: The University of Chicago Press, 2006. Print.

Schaffer, Kay and Sidonie Smith. Human Rights and Narrated Lives, The Ethics of Recognition. New York: Palgrave Macmillan, 2004. Print.

Smith, Sidonie and Julia Watson. Reading Autobiography, A Guide for Interpreting Life Narratives, Second Edition. Minneapolis and London: University of Minnesota Press, 2010. Print.

Smith, Sidonie and Julia Watson. "Witness or False Witness: Metrics of Authenticity, Collective I-Formations, and the Ethic of Verification in First-Person Testimony". In: Biography, Volume 35, number 4, Fall 2012, pp. 590-626. DOI: 10.1353/bio.2012.0047. Web.

Suljagic, Emir. Briefkaarten uit het graf, Een overlevende van Srebrenica vertelt. Translated by Guido Snel. Amsterdam: Uitgeverij de Arbeiderspers. 2006.

Sudetic, Chuck. Blood and Vengeance, One Family's Story of the War in Bosnia. New York: Penguin Books, 1998. Print.

Taylor, Charles. The Ethics of Authenticity. Cambridge MA: Harvard U P. 1991, Print.

\section{ABOUT THE AUTHOR}

Odile Heynders is a Professor of Comparative Literature in the Department of Culture Studies at Tilburg University and was a fellow at NIAS (Netherlands Institute for the Advanced Study in the Humanities) in 1998/99, and 2004/05. She has published books (in Dutch) on modernist strategies of reading, European poetry, Dutch public intellectual Paul Rodenko, and the history of literature studies in the Netherlands. Her current research project is on writers as European public intellectuals and celebrities.

Heynders is Head of the Research Programme: Literature and Visual Art in the European Public Sphere and supervisor, together with sociolinguist Jan Blommaert, of the junior research team (PhD's \& Post docs) TRAPS: Transformations of the Public Sphere. She was member of the Core Staff of the Liberal Arts Bachelor at 
Tilburg University (2004-2010) and is the Coordinator of the Tilburg Honours Programme European Discourses.

\section{NOTES}

1 Obviously, in the context of a 7000 words paper, I can only discuss part of this fascinating material.

2 Two contrasting narratives explain the massacres on a scale not seen since 1945. The first presents the Balkans as "a cauldron of mysterious squabbles and ancient hatreds" (Judt 2007 , p. 665). Six republics, five nations, four languages, three religions and two alphabets were held together by Tito's party, but when the communist leader died in 1980, age-old animosities and feelings of injustice reappeared with a vengeance. The second explanation emphasizes the outside interventions that caused the Yugoslavian tragedy. In the course of two centuries, Turkey, Britain, France, Russia, Austria, Italy and Germany had occupied, divided and exploited parts of the Balkans, and these imperial manipulations resulted in the exacerbation of ethnic, religious and local conflicts.

3 KRO De Reunie/Srebrenica, 16 jaar later ('Srebrenica, 16 years on'). Broadcast on Sunday April 24, 2011. < http://reunie.kro.nl/seizoenen/13/afleveringen/24-04-2011> [Accessed on 18 October 2013].

4 "We understand life narrative (...) as a general term for acts of self-presentation of all kinds and in diverse media that take the producer's life as their subject, whether written, performative, visual, filmic, or digital" (Smith and Watson 2010, p. 4).

5 The five metrics of authenticity are: 1 . The you-are-there sense of immediacy, 2. The invocation of rights discourse, 3 . The affirmation of the duty to narrate a collective story, 4. The normative shape of victim experience and identity, and 5. The ethno-documentation of cultural specificity. Smith and Watson 2012: 593-594. See: http://muse.jhu.edu/ journals/bio/summary/v035/35.4.smith.html [Accessed on 12 August 2013].

6 As he explains: "Literature does a kind of side-politics or meta-politics. The principle of that 'politics' is to leave the common stage of the conflict of wills in order to investigate in the underground of society and read the symptoms of history. It takes social situations and characters away from their everyday, earthbound reality and displays what they truly are, a phantasmagoric fabric of poetic signs, which are historical symptoms as well" (Rancière 2010, p. 163).

7 In Dutch: Briefkaarten uit het graf, Een overlevende van Srebrenica vertelt.

8 "Ik heb het overleefd. Mijn naam zou Muhamed, Ibrahim of Isak kunnen zijn, dat maakt niet uit, ik heb het overleefd en vele anderen niet. Ik heb het overleefd op dezelfde manier waarop zij zijn gestorven. Tussen hun dood en mijn voortleven bestaat geen enkel verschil omdat ik voortleef in een wereld die voorgoed en onherroepelijk is getekend door hun dood. Ik kom uit Srebrenica. Ik kom eigenlijk ergens anders vandaan, maar heb ervoor gekozen uit Srebrenica te zijn. Alleen daarvandaan durf ik te komen, zoals ik me alleen daarheen durfde te begeven in een tijd waarin ik nergens anders heen kon".

9 This reminds us of what Italian philosopher Giorgio Agamben discussed in Remnants of Auschwitz (2008, p. 16); Primo Levi did not consider himself a writer, he became a writer to bear witness, the writer exists in witnessing.

10 "Ik bevond me toen in Potocari, op de Nederlandse basis, waar ik als tolk werkte voor een driekoppig team oorlogswaarnemers van de VN. Het verraad dat ik heb gezien is anders dan het verraad dat de overlevenden van de slachting hebben gezien. (...) Wat ik heb gezien was kille, bureaucratische desinteresse, een verraad gepleegd door mensen die hadden doorgeleerd, naar alle maatstaven intelligente mensen. Mensen die in die dagen uitgerekend juist dat niet durfden of wilden zijn". 
11 In 2010, almost fifteen years after the massacre, which they had failed to prevent, commanders Karremans and Franken were accused (of being accessories to the execution of Muslims in Srebrenica) at the Public Court in Arnhem, by UN translator Hasan Nuhanovic and the relatives of Rizo Mustafic, who worked as an electrician at the base, was sent away, and killed just like Hasan's brother. See: De Groene Amsterdammer, 21-07-2010.

12 French general in charge of leading the UN Military Force.

13 Yasushi Akashi, the special representative to the UN force of Secretary-General Boutros Ghali even characterized the senior Muslim commanders in Srebrenica as 'criminal gang leaders, pimps, and black marketeers' (Sudetic 1998, p. 257) and Muslim commanders in Sarajevo took the decision to remove most of them from the safe area. That was in March 1995, three months before the massacre.

14 Friso Keuris studied at the Royal Academy The Hague (1982-1987) and is an Amsterdam based portraits photographer since 1989. He works in commission for a broad spectrum of leading national and international magazines and companies. Over the time he has portrayed a large group of famous and influential artists, writers, musicians, actors, important politicians and royalties. Regularly Keuris completes long-term personal projects. In these series he portrays the eyewitnesses of, and those whom are connected to, historical institutes and incidents. See his website: http://www.frisokeuris.com/portfolio.html [Accessed on 17 October 2013].

15 See for a part of the photo collection: http://www.frisokeuris.com/portfolio.html [Accessed on 17 October 2013].

16 "Na de val van Srebrenica reden we in een pantservoertuig met de vluchtelingen mee richting Potocari. Ons voertuig zat vol. Toch probeerden mensen bij ons in de wagen te komen. Het is verschrikkelijk maar tijdens die rit heb ik een jonge vrouw met kind van de YPR af moeten duwen. We zaten echt helemaal vol. Ik heb me dienstbaar kunnen maken, veel gewonden kunnen helpen en op die manier voldoening uit mijn uitzending kunnen halen. Zo'n uitzending doe ik nooit meer".

17 "Bij het afvoeren van de moslims met de bussen, moesten we helpen met het scheiden van de mensen. Het was één chaos. Twee Nederlandse luitenanten kregen ruzie omdat één van hen het niet eens was met de medewerking aan de Serven. Die vond het Nazipraktijken. Bij vertrek heb ik uit frustratie mijn eigen spullen in elkaar staan trappen. Niks wilde ik voor de Serven achterlaten".

18 "Wij moesten de moslimvrouwen vervoeren die bij ons op de compound werkten. Ze liepen via de planken omhoog de vrachtwagen in. Het duurde niet lang, of wij zagen het als een soort veetransport. Door zo te denken, spaarde ik mijn gevoelens. Het was echt de knop omzetten".

19 Arendt discusses the example of Eichmann thinking in terms of "forced emigration" when in fact the Endlösung had started. Eichmann considered himself a man of order and procedures, just following up the orders from higher officials. (p. 269)

20 Translation H.W.A. J. Verhulst, Tilburg University, School of Humanities.

21 "En of je nou 500 of 700 man extra had gehad, tegen een overmacht van Bosnische Serven die stijf van de drugs stonden met al hun oorlogstuig, daar was geen houden aan”.

22 "Dutchbat arriveerde in 1994 in een enclave met uiterst gecompliceerde verhoudingen en was slecht geprepareerd op de feitelijke situatie aldaar. (...) Dat droeg bij tot een in zichzelf gekeerde mentaliteit en een versterking van negatief gekleurde stereotype opvattingen. Dutchbat was vaak negatief over de bevolking in de enclave, maar van een doelbewuste anti-moslim houding was geen sprake”. See: NIOD report, 4th statement in Press Summary.

23 The OED marks the subtle differences: Imaginary = existing only in the imagination, Imaginative $=$ having or showing creativity or inventiveness, Imaginable $=$ possible to be thought of or believed. 